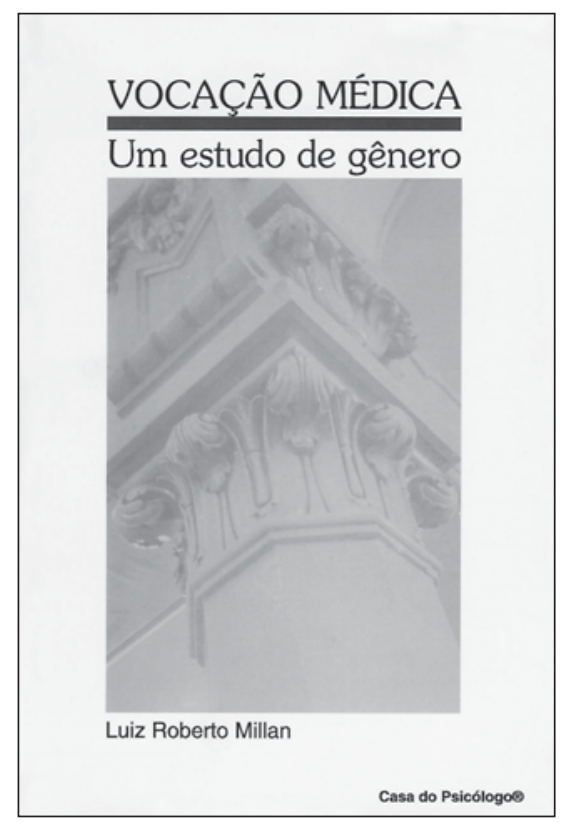

\section{Vocação Médica Um Estudo de Gênero}

\author{
Luiz Roberto Millan \\ Casa do Psicólogo
}

A medicina, uma das mais antigas profissões da história da humanidade, desenvolveu-se nas últimas décadas de forma extraordinária quanto ao aspecto técnico. Conforme destaca Luis Roberto Milan, autor do livro, esse progresso e a formação de novos profissionais não foram acompanhados da suficiente valorização do que existe de muito precioso para o desempenho da tarefa médica: a relação médico/paciente. Segundo algumas referências apresentadas na obra, houve até um retrocesso nesse aspecto.

0 autor do livro é psiquiatra e psicanalista dedicado à assistência aos alunos da Faculdade de Medicina da Universidade de São Paulo (FMUSP). Há cerca de 20 anos vem executando essa tarefa com grande êxito, o que tornou o Grupo de Assistência Psicológica ao Aluno da Faculdade de Medicina da USP (GRAPAL) uma referência nacional. O livro tem como público-alvo médicos - particularmente os psiquiatras-, psicólogos, psicanalistas, estudantes, professores dessas áreas, além de outros profissionais das áreas de saúde e educação, e objetiva contribuir para 0 aprimoramento da formação e da prática do médico.

A questão da vocação médica é milenar. Hipócrates, por exemplo, o Pai da Medicina, há 2.400 anos já citava os atributos necessários para aqueles que pretendiam abraçar a profissão médica na época. Muitos desses atributos, surpreendentemente, são válidos até hoje. Tomemos como exemplo uma assertiva de Hipócrates: "O tratamento das enfermidades implica dois pontos fundamentais: ser útil e não causar nenhum dano. Nossa arte engloba três aspectos: a enfermidade, o enfermo e o médico; o médico é um servidor da arte e o enfermo deve lutar contra a enfermidade junto com o médico".

Com o intuito de abordar o tema e relacioná-lo com as questões ligadas ao gênero, tema central do livro que se origina da tese de doutoramento, Milan realiza uma revisão bibliográfica extensa e crítica que abrange desde a história da profissão médica até as teorias vocacionais, com ênfase nas de orientação psicanalítica.

Na parte seguinte, propõe uma metodologia para o estudo do tema e apresenta os resultados de uma pesquisa realizada com alunos da FMUSP. Quanto à metodologia, o autor afasta-se da posição dogmática de considerar apenas a metodologia quantitativa a única no campo da psiquiatria e da saúde mental, valendo-se tanto da metodologia qualitativa quanto da quantitativa. Eis outra qualidade e exemplo para futuros trabalhos em nossa disciplina.

$O$ livro é fruto da dedicada atividade realizada pelo autor junto aos estudantes de medicina da USP. Aliada ao seu talento clínico, desenvolve uma pesquisa com metodologia científica rigorosa, original em vários de seus detalhes, o que lhe confere as características de uma tese pela contribuição ao saber que realiza.

Destaca-se por abordar aspectos dos mais desafiadores da psicologia médica: a vocação. Ao questionar a amostragem investigada e a questão da vocação médica, ele sentencia: "Talvez o conceito de vocação médica seja tão abstrato que não possa ser expresso em palavras, ou seja, estaria incluído na categoria dos conceitos inefáveis, assim como acontece com os sentimentos, que todos sabem o seu significado, mas ninguém é capaz de defini-los, contentando-se apenas em descrever as situações em que se tornaram presentes". O famoso Professor Lopes Ibor, em Temas de Psicologia Médica, apresenta idéia semelhante, mas a expressa de modo diferente. Esta obra é lançada ao público especializado para preencher uma lacuna em nosso meio ao abordar a preconceituosa questão do gênero na vocação médica.

Por fim, cabe destacar algumas das conclusões do livrotese: 1) o nivel socioeconômico é um fator limitante para o ingresso na FMUSP; 2) alunos de ambos os gêneros possuem uma visão hipocrática, ou seja, humanista da medicina; 3) a entrevista e o teste projetivo mostraram que os alunos possuem verdadeira predisposição altruísta e que a profissão médica ocupa posição central em suas vidas; e 4) a vocação médica transcende o gênero.

Theodor Lowenkron

Livre-docente e professor associado de Psiquiatria e Saúde Mental da Faculdade de Medicina da Universidade Federal do Rio de Janeiro (UFRJ) 